\title{
A Comparison of the Green Building's Criteria
}

\author{
A.Y. Bahaudin ${ }^{1}$, E.M. Elias ${ }^{2}$, A.M. Saifudin ${ }^{3}$ \\ ${ }^{1,2,3}$ School of Technology Management \& Logistics, College of Business, Universiti Utara \\ Malaysia, 06010 Sintok, Kedah, MALAYSIA
}

\begin{abstract}
Designers and clients alike are now emphasising on how to make their buildings green. Currently a lot of green councils worldwide are dealing with innovative ways to implement energy efficient new buildings. They have adopted various criteria and rating systems in an endeavour to classify buildings that contribute to environment sustainability, efficiency and users health. The aim of the paper is to present an overview of the criteria adopted by selected green building councils. This paper discusses five of the rating systems available in terms of their similarities and differences and proposes a new framework based on the project life cycle for the development of the green building criteria. Criteria during the construction phase of the building is certainly lacking such as pollution control in terms of $\mathrm{CO}_{2}$ emission, dust, and other pollutants.
\end{abstract}

\section{Introduction}

Business organizations, governments and people around the globe have been implementing approaches to make our planet as 'green living'. They have replanted thousands of trees, control greenhouse gases, earth hour campaigns, and innovation adoption via hybrid cars, reuse materials, wind and solar energy exploitation. The broad definition of green living is any of human actions or activities that results in a positive impact, to any amount, on the environment and the Earth which can reduce their endurance to support future generations. The goal of green living is to preserve and improve the health of human being as well as the 'Earth' from the harmful environmental pollutants and emissions. People are now talking of how to make their buildings green. They want to have a place like a house or work in the building which has less negative impact to environment such as $\mathrm{CO}_{2}$ emissions and pollution. That is because buildings have a significant and continuously increasing the impact to the environment through $\mathrm{CO}_{2}$ releases. They also created the most waste, use most of nonenergy related resources, and as a source of major pollutions (sound, air and water). In the UK for example, in 2010, a survey have concluded that buildings contributed to about $50 \%$ of UK's $\mathrm{CO}_{2}$ emissions and another $7 \%$ due to new building construction [2]. In addition, about $10 \%$ of the global economy involves the construction and operations of buildings which are using $17 \%$ to $50 \%$ of the world's natural resources that can cause the most extensive environmental damage. Hence, buildings and building construction are not only damaging to the environment but to the people who live inside as well. For example, the building interiors subject the owners to indoor air quality environments that affect people's health, safety, welfare, and performance.

The selection of building materials also plays an important role for a more sustainable building. It is suggested that if buildings are made from timber for example, it will reduce almost $50 \%$ of $\mathrm{CO}_{2}$ emissions [3]. Thus, it becomes one of the important criteria for developing an efficient building 
where materials that easily contribute to $\mathrm{CO}_{2}$ emission can be controlled. Currently, most green councils worldwide deal with innovative ways of creating energy efficient new buildings also known as green buildings. Green building is a set of practising human activities to increase the efficiency in which the buildings use and harvest energy, water, and materials. The goal is to reduce the building's (and its operations) impacts on human health and conditions as well as the environment, through a better positioning, design, construction, operation, maintenance, and the complete building life cycle. Generally, all green buildings are designed to save energy and resources, to use the right materials (economical, recycled, strong, etc.) and to minimize the emission of toxic substances throughout its life cycle. A green building can also reduce the undesirable human impacts on the natural surroundings, building materials, building assets, and enhances human health and the natural environment [7].

\section{Methodology}

In general, the data collections for the study were through qualitative approaches where logical analysis and face-to-face interviews (semi-structured) were carried out. Online journals, websites and articles were gathered on related issues relevant to the study's objective and became the initial method to collect data. The priority is to focus on the five countries that implement the green building rating systems for non-residential new construction namely Malaysia, Singapore, USA, Indonesia and South Korea. These rating systems were analysed based on their criteria in terms of similarities and differences. Face-to-face interviews were also conducted on three respondents from three different organizations; the Ministry of Energy, Green Technology and Water, Malaysia (KeTTHA), the Malaysian Green Building Index (GBI), and the Selangor State Development Corporation (PKNS). This paper is aimed to widen the criteria for the green rating tools to the life cycle of the building by proposing new criteria. From the analysis, this study will propose new criteria in addition to the current available criteria for green buildings. At present, there is no common standard set of criteria for the rating of green buildings where each country has their own rating systems, even Malaysia has more than one rating tools developed by various organisations. Moreover, the criteria developed are mostly applicable to the current building in operation and not taking into account the planning, design and construction phases for criteria development.

This paper is organized as follows; the initial sections consist of the introduction to green buildings, the definition, aims and the methodology. Later sections discussed about the green building's definition and the rating systems from five countries. The findings section will analyse the similarities and differences of the green building rating systems and the conclusions proposed a new framework consisting of new criteria.

\section{Literature Review}

This section presents the definition of green building and investigates green building criteria as adopted by major green building councils.

\subsection{Definitions}

The US Green Building Council defines 'Green Building' as "the significant reduction or elimination of the negative impact of buildings on the environment and on the building occupants. Green building design and construction practices address: sustainable site planning, safeguarding water and water efficiency, energy efficiency, conservation of materials and resources, and indoor 
environmental quality" [10]. Other definition is proposed by GBI (Malaysia) which states "A Green building focuses on increasing the efficiency of resource use - energy, water, and materials - while reducing building impact on human health and the environment during the building's lifecycle, through better sitting, design, construction, operation, maintenance, and removal. Green Buildings should be designed and operated to reduce the overall impact of the built environment on its surroundings."

By improving on the efficiency of active systems through mechanical and electrical equipment plus with a proper sustainable maintenance administration, significant reductions in consumed energy can be realized. Examples are mechanical ventilation for roofs and windows for fresh air intake and stale air expulsion; electrical usage can be reduced by selecting efficient appliances and lamps; incorporating day-lighting strategies that reduce the need artificial light such as photovoltaic components, automatic electricity cut-off systems and wind generator.. This can lead to reduced $\mathrm{CO} 2$ emissions and increase long-term savings for the building owners.

\subsection{Green Building Councils - The criteria and rating systems}

World Green Building Council (WGBC) is an alliance of 80 national Green Building Councils worldwide and serve as the largest international organizations that influence the green buildings marketplace. The mission is to facilitate worldwide nations to transform building construction from the conventional practices into a more sustainable and green approach through market driven mechanisms. Two of the important global issues that they have addressed are related to the climate change and $\mathrm{CO}_{2}$ emissions. In addition, a WGBC function is to support the adoption of market-based green building through some criteria and rating systems. Some of the established criteria and rating systems around the world are: (i) LEED (US), (ii) Green Star (Australia and New Zealand), (iii) GBI (Malaysia), (iv) Green Mark (Singapore), (v) KGBCC (South Korea), (vi) CASBEE (Japan), and (vii) Green Ship (Indonesia). However this study will focus only on GBI, Green Mark, KGBCC, Greenship and LEED.

\subsubsection{GBI (Green Building Index)}

The GBI is officially launched on August 2008 by PAM (the Association of Architects, Malaysia) and exclusively designed for tropical climate (hot and humid condition). The GBI Non-Residential Rating tool evaluates the sustainable aspects of buildings that are commercial, institutional and industrial in nature. This includes factories, offices, hospitals, universities, colleges, hotels and shopping complexes. In the GBI rating (see Table 1), more focus is placed on energy efficiency (35 points) and indoor environmental quality ( 21 points) as these have the greatest impact in the areas of energy use and well-being of the residents and users of the building. GBI looks into six main criteria such as Energy Efficiency, Indoor Environment Quality, Sustainable Site Planning \& Management, Materials and Resources, Water Efficiency and Innovation.

The total points for all criteria is 100 and to achieve the points, building company will comply with necessary possessions so that the building will likely be more green environment-friendly. In addition, under the GBI assessment framework, some points will also be granted for achieving and integrating environment-friendly features which are above current industry practice. Based on scoring, the building will be awarded Platinum, Gold, Silver or GBI Certified. Table 1 illustrates the scores and ratings for GBI. 
Table 1: GBI Scoring and Rating Award for Non Residential - New Construction Building

\begin{tabular}{|l|c|c|c|}
\hline \multicolumn{1}{|c|}{ Criteria } & Scoring & Total Score & Rating Award \\
\hline Energy Efficiency & 35 & 86 and above & GBI Platinum \\
\hline Indoor Environmental Quality & 21 & 76 to 85 & Gold \\
\hline Sustainable Site Planning \& Management & 16 & 66 to 75 & Silver \\
\hline Material and Resources & 11 & 50 to 65 & Certified \\
\hline Water Efficiency & 10 & & \\
\hline Innovation & 7 & \multicolumn{2}{|c|}{} \\
\hline Total & 100 & \multicolumn{2}{|c|}{} \\
\hline
\end{tabular}

\subsubsection{Green Mark}

The Green Mark is introduced in January 2005 by Singapore's Building Construction Authority. The objective is to establish the construction industry towards producing a more environment-friendly building. It is also to promote sustainability in the built environment and increase environmental responsiveness among developers, designers and builders. Among the benefits of Green Mark includes; facilitate reduction in water and energy bills, reduce potential environmental impact, improve indoor environmental quality for a healthy and productive workplace, and provide clear direction for continual improvement.

Green Mark is a green building rating system which evaluates a building for its environmental impact and performance. It provides a comprehensive framework for assessing the overall environmental performance of new and existing buildings. Under the assessment framework for new buildings, developers and design teams are encouraged to design and construct green, sustainable buildings which can promote energy savings, water savings, and healthier indoor environments. As for existing buildings, the building owners and operators are encouraged to meet their sustainable operations goals and to reduce adverse impacts of their buildings on the environment and occupant health over the entire building life cycle. The assessment criteria cover the five key areas: Energy Efficiency, Water Efficiency, Environmental Protection, Indoor Environmental Quality, and Other Green Features and Innovation.

The assessment identifies the specific energy efficient and environment-friendly features and practices incorporated in the projects. Points are awarded for incorporating environment-friendly features which are better than normal practice. The total number of points (190) obtained will provide an indication of the environmental friendliness of the building design and operations. Depending on the overall assessment and point scoring, the building will be certified to have met the Green Mark Platinum, Gold ${ }^{\text {Plus }}$, Gold or Certified rating (see Table 2).

Table 2: Green Mark Scoring and Rating Award for Non Residential-New Construction Building

\begin{tabular}{|l|c|c|c|}
\hline \multicolumn{1}{|c|}{ Criteria } & Scoring & Total Score & Rating Award \\
\hline Energy Efficiency & 116 & 90 and above & Green Mark Platinum \\
\hline Water Efficiency & 17 & 85 to 90 & Gold ${ }^{\text {Plus }}$ \\
\hline Environmental Protection & 42 & 75 to 85 & Gold \\
\hline Indoor Environmental Quality & 8 & 50 to 75 & Certified \\
\hline Green Features and Innovation & 7 & & \\
\hline Total & 190 & & \\
\hline
\end{tabular}

\subsubsection{Green Ship}

Participation of Indonesia in implementing green building principles was mainly through public and private sectors, associations and academic institutions. Indonesia by practice focuses on both 
newly-built and old buildings. The application of green building principles that been carried out have reflected some sort of benefits towards lower operating, lower energy and less waste. Basically through Green Building Council Indonesia (GBCI) having objectives in promoting the implementation of green building principles for all building sectors in their country, and one of the efforts is by developing a rating system "Greenship" kind of certification for buildings to achieve a green standard. The Greenship has been launched in $17^{\text {th }}$ June 2010 and it is one of the kinds rating to establish and used to benchmark the environmental capability or performance of different buildings. The assessment criteria cover the six key areas: Appropriate Site Development, Energy Efficiency and Conservation, Water Conservation, Material Resource and Cycle, Indoor Health and Comfort, and Building Environment Management.

Table 3: Greenship Scoring and Rating Award For Non Residential-New Construction Building

\begin{tabular}{|l|c|c|c|}
\hline \multicolumn{1}{|c|}{ Criteria } & Scoring & Total Score & Rating Award \\
\hline Energy Efficiency and Conservation & 26 & 80 and above & Greenship Platinum \\
\hline Water Conservation & 21 & 60 to 79 & Gold \\
\hline Appropriate Site Development & 17 & 50 to 59 & Silver \\
\hline Material Resource and Cycle & 14 & 40 to 49 & Certified \\
\cline { 1 - 2 } Indoor Health and Comfort & 10 & \multicolumn{2}{|}{} \\
\cline { 1 - 2 } Building Environmental Management & 13 & \multicolumn{2}{|}{} \\
\cline { 1 - 2 } Total & 101 & & \\
\cline { 1 - 2 }
\end{tabular}

The total rating for the Greenship is 101 and most important criteria are energy efficiency and conservation which carry 26 points. Thus the building will be awarded Platinum, Gold, Silver or Certified depending on total points from those six criteria (see Table 3 ).

\subsubsection{KGBCC}

The first initiative of green building systems for office and residential buildings in South Korea had begun between years 1997 to 2000. Then in 2001, the system has enhanced into Green Building Certification Criteria (GBCC) by Korea Institute of Energy Research (KIER) which based on green building tool. Now, the KGBCC has extended its areas to include the semi-residential buildings, office buildings (public and private), commercial buildings and re-modelled buildings. One of the main reasons why South Korea is highlighting on green buildings is because the country has the lowest rate of energy efficiency consumption. They had 0.351 per US\$1 as compared to Japan (0.106) and UK (0.152) (see Figure 1). Currently, KGBCC focuses on four main criteria (see also Table 4): Land Use and Commuter Transportation, Energy Resources Consumption and Environmental Loads, Ecological Environment, and Indoor Environment Quality.

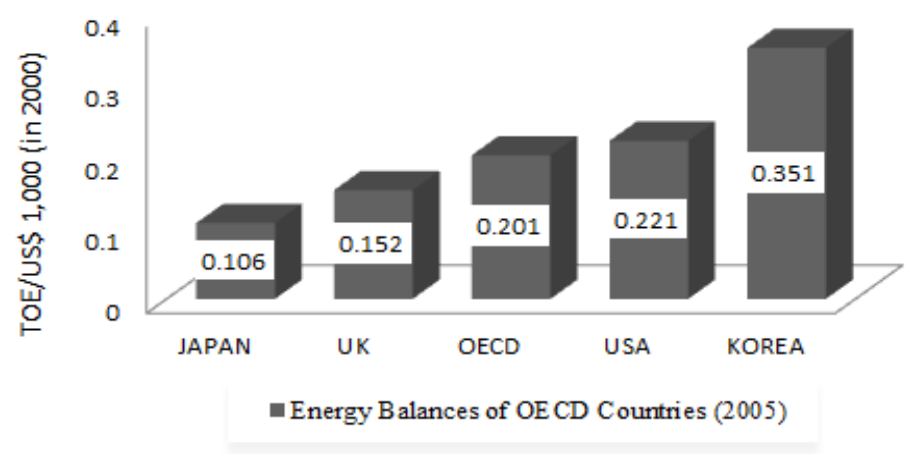

Figure 1: Comparison of Energy Efficiency 
Table 4: KGBCC Scoring and Rating Award for Non Residential-New Construction Building

\begin{tabular}{|l|l|c|c|c|}
\hline Criteria & Scoring & Total Score & Rating Award \\
\hline \multirow{2}{*}{$\begin{array}{l}\text { Land Use and Commuter } \\
\text { Transportation }\end{array}$} & Land Use & 7 & 85 and above & KGBCC Best \\
\cline { 2 - 3 } & Transportation & 5 & 65 to 84 & Excellent \\
\hline $\begin{array}{l}\text { Energy Resources } \\
\text { Consumption and } \\
\text { Environmental Loads }\end{array}$ & Energy & 23 & & \\
\cline { 2 - 3 } & Material Resources & 21 & & \\
\cline { 2 - 3 } & Water Resources & 14 & \\
\cline { 2 - 3 } & Environmental Pollution Loads & 6 & \\
\cline { 2 - 3 } & Management & 10 & \\
\hline Ecological Environment & Ecological Environment & 19 & \\
\hline $\begin{array}{l}\text { Indoor Environmental } \\
\text { Quality }\end{array}$ & Indoor Environmental Quality & 31 & & \\
\hline & & 136 & & \\
\hline
\end{tabular}

All the criteria have been established for numerous types of buildings either for Non Residential New Building and Residential New Building. Two most important factors for the KGBCC are Energy Resources Consumption and Environmental Loads (74 points) and Indoor Environmental Quality (31 points). The total points for all criteria is 136 points and only two rating awards offered; 85 points above will be awarded KGBCC Best and between 65 to 84 points can be credited as Excellent.

\subsubsection{LEED Green Building Rating System}

LEED is a highly quantified and systematic approach to buildings of all types. Because it has accomplished so much and been so broadly accepted, LEED is becoming the standard by which many green buildings are measured. LEED quantifies a building's performance in the following major categories as shown in Table 5. LEED operates through the U.S. Green Building Council and takes a much broader "triple bottom line" approach considering people, planet and profit, not just energy use. The triple bottom line factors in the economic, environmental and social issues present throughout the entire building process from concept, design, development and future operation.

Table 5: LEED Scoring and Rating Award for New Construction Building \& Major Renovations

\begin{tabular}{|l|c|}
\hline \multicolumn{1}{|c|}{ Criteria } & Scoring \\
\hline Energy and Atmosphere & 17 \\
\hline Water Efficiency & 5 \\
\hline Sustainable Sites and Transportation & 14 \\
\hline Indoor Environment Quality & 15 \\
\hline Material and Resources & 13 \\
\hline Innovation \& Design Process & 5 \\
\hline Total & 69 \\
\hline
\end{tabular}

\section{Findings}

The results of this study can be summarised in Table 6 and Table 7 which shows the percentage utilisation of the green building criteria by various councils and a comparison of the green building criteria respectively. It is clear from Table 6 that Energy Efficiency, Water Efficiency and Indoor Environment Quality are the most vital elements (as they are being referred to by all the councils) to be considered in the green building criteria development by the councils under consideration, followed by Site Planning \& Management, Materials \& Resources, Environmental Protection and Innovation. 
Energy Efficiency encompasses design and performance, commissioning, monitoring, improvement \& maintenance with a 38\% maximum score for GBI, $61 \%$ for Green Mark, $26 \%$ for Greenship, 17\% for KGBCC and $25 \%$ for LEED. Water Efficiency includes water harvesting and recycling with a $12 \%$ maximum score for GBI, 9\% for Green Mark, 21\% for Greenship, 10\% for KGBCC and 7\% for LEED. Indoor Environment Quality takes into account air quality, thermal, lighting, visual and acoustic comfort, and verification with a $21 \%$ maximum score for GBI, $4 \%$ for Green Mark, $10 \%$ for Greenship, 23\% for KGBCC and 22\% for LEED. Materials \& Resources include reused, recycled and sustainable materials and resources.

This criterion also takes into account waste management and green products. GBI allocated a 9\% score for these criteria with Greenship's score of $14 \%$, KGBCC's score of 4\% and LEED's 19\%. Site Planning \& Management criteria encompass facility management, transportation and the reduction of the heat island effect. GBI allocated a 10\% score for these criteria with Greenship's, KGBCC's and LEED's score of $17 \%, 7 \%$ and $10 \%$ respectively. These two criteria however are not applicable for Green Mark's assessment for green buildings. The distribution of scores for other criteria by the councils under study is illustrated in Table 7. It can be seen (from Table 7) that energy efficiency is the most influential criteria $(36.4 \%)$ followed by indoor environment quality (14.3\%) whilst transport and land use are the least influential (with only $2 \%$ and $1 \%$ utilisation respectively) criteria for the assessment of green buildings as allocated by the councils under study.

Table 6: Percentage Utilisation of the Green Building Criteria

\begin{tabular}{|c|c|c|c|c|c|c|}
\hline \multicolumn{1}{|c|}{$\begin{array}{c}\text { Energy } \\
\text { Efficiency }\end{array}$} & $\begin{array}{c}\text { Water } \\
\text { Efficiency }\end{array}$ & $\begin{array}{c}\text { Indoor } \\
\text { Environment } \\
\text { Quality }\end{array}$ & $\begin{array}{c}\text { Site Planning } \\
\text { and } \\
\text { Management }\end{array}$ & $\begin{array}{c}\text { Innovatio } \\
\mathrm{n}\end{array}$ & $\begin{array}{c}\text { Materials \& } \\
\text { Resources }\end{array}$ & $\begin{array}{c}\text { Environmental } \\
\text { Protection }\end{array}$ \\
\hline $100 \%$ & $100 \%$ & $100 \%$ & $80 \%$ & $60 \%$ & $80 \%$ & $60 \%$ \\
\hline Transport & Land Use & $\begin{array}{c}\text { Ecological } \\
\text { Environment }\end{array}$ & \multicolumn{1}{|l}{} & \\
\hline $20 \%$ & $20 \%$ & $20 \%$ & & & \\
\cline { 1 - 3 } & &
\end{tabular}

Table 7: A Comparison of the Green Building Criteria by Various Green Building Councils

\begin{tabular}{|l|c|c|c|c|c|c|}
\hline \multicolumn{1}{|c|}{ Criteria } & GBI & Green Mark & Green Ship & KGBCC & LEED & Total \\
\hline Energy Efficiency & $\sqrt{ }(38)$ & $\sqrt{ }(61)$ & $\sqrt{ }(26)$ & $\sqrt{ }(17)$ & $\sqrt{ }(25)$ & $36.4 \%$ \\
\hline Water Efficiency & $\sqrt{ }(12)$ & $\sqrt{ }(9)$ & $\sqrt{ }(21)$ & $\sqrt{ }(10)$ & $\sqrt{ }(7)$ & $11.2 \%$ \\
\hline Indoor Environment Quality & $\sqrt{ }(21)$ & $\sqrt{ }(4)$ & $\sqrt{ }(10)$ & $\sqrt{ }(23)$ & $\sqrt{ }(22)$ & $14.3 \%$ \\
\hline Site Planning and Management & $\sqrt{ }(10)$ & & $\sqrt{ }(17)$ & $\sqrt{ }(7)$ & $\sqrt{ }(10)$ & $8.4 \%$ \\
\hline Innovation & $\sqrt{ }(10)$ & $\sqrt{ }(4)$ & & & $\sqrt{ }(7)$ & $3.2 \%$ \\
\hline Materials \& Resources & $\sqrt{ }(9)$ & & $\sqrt{ }(14)$ & $\sqrt{ }(15)$ & $\sqrt{ }(19)$ & $9.9 \%$ \\
\hline Environmental Protection & & $\sqrt{ }(22)$ & $\sqrt{ }(13)$ & $\sqrt{ }(4)$ & & $10.2 \%$ \\
\hline Transport & & & & $\sqrt{ }(4)$ & $\sqrt{ }(10)$ & $2.0 \%$ \\
\hline Land Use & & & & $\sqrt{ }(5)$ & & $1.2 \%$ \\
\hline Ecological Environment & & & & $\sqrt{ }(14)$ & & $3.2 \%$ \\
\hline Total & $100 \%$ & $100 \%$ & $100 \%$ & $100 \%$ & $100 \%$ & $100 \%$ \\
\hline
\end{tabular}

Note: Numbers in brackets are percentages.

GBI and LEED developed six (6) criteria that are similar but differ in emphasis (scores or points). GBI places more emphasis on Energy Efficiency, Water Efficiency and Innovation whereas LEED places more emphasis on Site Planning \& Management, and Materials \& Resources. Both GBI and LEED placed equal emphasis on Indoor Environment Quality. Green Mark opted out Materials \& Resources and Site Planning \& Management criteria (as noted previously) but included Environmental 
Protection (22\%) which is only second in emphasis to Energy Efficiency (61\%). Environmental Protection is also included in the Greenship and KGBCC assessment for green buildings but Innovation is not applicable. KGBCC introduces other criteria such as Transport, Land Use and Ecological Environment which are not considered by other councils in this study.

Innovation (refer to Table 6 and Table 7) is also an important criterion in the green building assessment as it is being taken into account by sixty per cent $(60 \%)$ of the respondents under the scope of this study, although its weightage is only about three per cent $(3.2 \%)$ of all the criteria being considered. Industrialised building system (IBS) is a construction technique that is innovative [11, 12] and contributes to sustainability where the components are manufactured in the factory, hence contribute minimal effect to the environment. The Malaysian authority is now encouraging clients, developers and contractors to utilise IBS in an effort to contribute to environmental sustainability. This is reflected in recent rating tools being developed by the Malaysian construction industry development board (CIDB) and the Malaysian public works department (JKR).

Traditional architecture can also contribute to environmental sustainability [13], as was being investigated in Iran and can be seen in the traditional Malay houses where ventilation is fully maximised and sunlight fully utilized. The Godalbaghche architecture in Iran was found to utilise natural energy as was reported by Ebadi et. al.[13]

\section{Discussions and Conclusions}

The various criteria discussed for the assessment of green buildings however are mainly focussed on the actual completed building (operations and maintenance phase). No doubt these criteria are of greatest importance to the current building but consideration must also be given to the planning, design and construction phases that the building has gone through. In other words, the assessment should also take into account whether the building has been subjected to green planning, design and construction or whether the building has gone through a green project life cycle. If criteria are to be developed for the planning, design and construction phases, the operation and maintenance phase of a building, however, will still carry the most weightage towards the assessment for a green building. Figure 2 shows the life cycle of a building and its impact on the environment. The construction phase will no doubt contribute the highest intensity of impacts to the environment, and this should be taken into account and also into the assessment of green buildings. From the discussion of the rating tools and criteria in Section 2.0, the only criterion that has relevance to the pre-operational stage of a building is Materials and Resources where emphasis is on recycled, reused sustainable materials and green products during the construction phase. Sustainable purchasing policy and the storage and disposal of materials are also part of the criteria which is mostly adopted by the councils under study. However the authors feel that more criteria should be developed for the planning, design and construction stages of a building life cycle in the assessment for green buildings. Criteria during the construction phase of the building, for example, is certainly lacking such as pollution control in terms of $\mathrm{CO}_{2}$ and $\mathrm{CO}$ emissions, wastage, dust and other pollutants. The equipments, plant and machineries that were employed during the construction phase of a building project will definitely contribute to the pollution of the environment during that particular period of time. A method of construction that favours the reduction of pollution (air and noise) to the environment will definitely make a building more sustainable for example a bored- pile construction method as opposed to a driven- pile one. Hence the method of construction should be a criterion in the rating system. The same goes to the machineries utilised during construction, whether they are subjected to adequate maintenance procedures or not.. Value engineering can also contribute towards a more sustainable building and by incorporating a criterion for value engineering in the planning and design phases the negative effects to the environment can be minimised and controlled. Building aesthetics is secondary but effects to 
the environment, wastage and disposal of wastes (during the entire life cycle of the building) are important criteria that are vital for a building to be classified as sustainable. Excessive wastage of materials will result in increased pollution Therefore it is necessary to include a criterion to measure wastage during construction. Figure 3 shows a framework based on the project life cycle where criteria are developed.

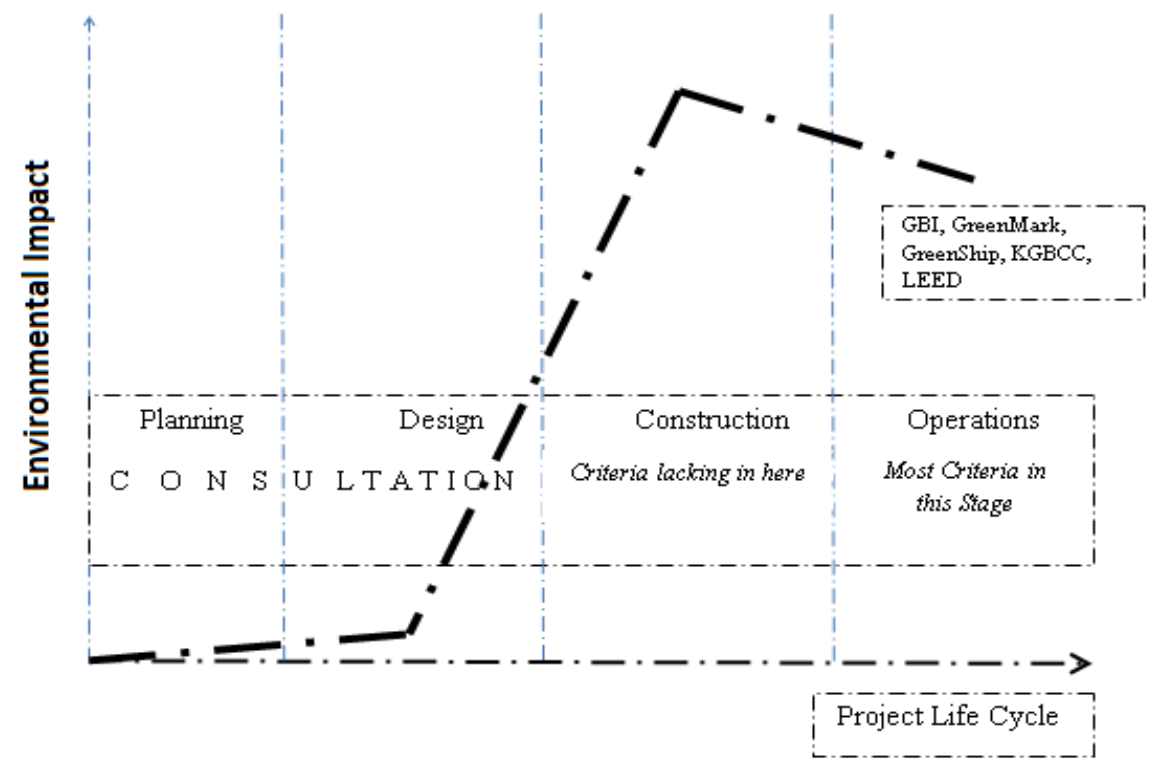

Figure 2: Environmental Impact Intensity \& Criteria Development during the Project Life Cycle.

The respondents interviewed agreed for clients to acquire green building accreditations for their buildings. And this is even more relevant before construction and during the early stages of the project life cycle, but costs seemed to be the main barrier to its implementation. Furthermore there are a number of other green building rating tools recently developed by organisations in Malaysia such as Green Pass (by the Construction Industry Development Board, CIDB), Green Re (by the Real Estate Housing Development Authority, REHDA), Penarafan Hijau (Green Ranking by the Public Works Department, JKR) besides GBI. Therefore the awareness in the concept of sustainability in buildings in Malaysia is increasing and some of these organisations are willing to have discussions for the possibility of integrating some of these rating tools

The housing developers in Malaysia are however only moderate in terms of their readiness to develop green houses [14] as opposed to CIDB and JKR who are more committed in environmental sustainability for their projects.

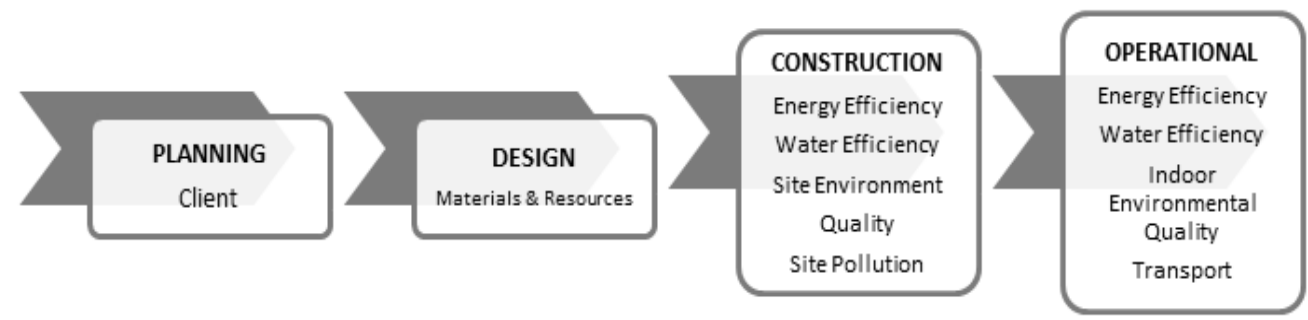

Figure 3: Criteria Development: The Green Building Criteria Framework 


\section{References}

1. Castro, D., Sefair, J.A., Florez, L., and Medaglia, A.L. (2009). Optimization model for the selection of materials using a LEED-based green buildings ratings system in Columbia. Journal of Building and Environment. 4, pp. 1162-1170.

2. NBS (Natural Business Solutions). The Environmental Impact. Available at: http://www.naturalbuilding.co.uk/environmental_impact.html. (Accessed 23 November 2011)

3. Thomark, C. (2007). Energy and resources, materials choice and recycling potential in low energy buildings. Proceedings of Portugal SB07, sustainable construction, materials and practices. IOS Press, pp. 759-766

4. Tony Arnel (2011). Green Buildings. Available at: http://www.greenbuildingindex.org/whygreen-buildings.html, (Accessed 25 November 2011).

5. GBI (Green Building Index). The Rating System. Available at: http://www.greenbuildingindex.org/. (Assessed 12 October 2011).

6. WRAP (Waste and Resource Action Programme). Resource Efficiency. Accessed on: http://www.wrap.org.uk/business/, 23 November 2011, 13.14pm

7. Okhovat, H., Amirkhani, A., and Pourjafar, M.R. (2009). Investigating the psychological effects of sustainable buildings on human life. Journal of Sustainable Development. 2 (3): 57-63

8. Roodman, D.M. and Lenssen, N. (1995). A building revolution: How ecology and health concerns are transforming construction. WorldWatch Paper, no. 124, pg. 5. World watch Institute, Washington DC.

9. Preston (2009). New AES Wind Jet 5 Small Wind Turbine Installed In Kansas City. Available at: http://www.jetsongreen.com/2009/11/aes-windjet-5-vawt-small-wind.html (Accessed 30 Nov 2011)

10. US Green Building Council (2003) The Impact of LEED $_{\mathrm{TM}} 2.1$ On Wood Markets. Available at: http://www.awc.org/pdf/TheImpactofLEED.pdf (Accessed 23 March 2012)

11. Onyeizu, E.N.and Abu Bakar A.H.,2011. The Utilization of Industrialized Building System in Design Innovation in Construction Industry, World Applied Science Journal 15 (2): 205-213. IDOSI Publications.

12. Mirsaeedie, L., 2012. Application of Industrialised Building System (IBS) in Rural Settlements Towards Sustainability, World Applied Science Journal 16 (5): 729-733. IDOSI Publications.

13. Ebadi, H.,Lamit, H., Yegane, S., Kermaji, R., Bigdelirad, V., 2014. A Survey on Sustainability of Central Courtyards of Iran Traditional Architecture, World Applied Science Journal 30 (Innovation Challenges in Multidisciplinary Research \& Practice): 221-225. IDOSI Publications.

14. Ibrahim, F.A., Mohd. Shafiei, M.W., Said, I., Ismail, R., 2013.Malaysian Housing Developer's Readiness in Green Homes Development, World Applied Science Journal 28 (3): 343-352. IDOSI Publications. 